\title{
INFLUENCE OF DEPECTINIZATION IN THE ULTRAFILTRATION OF WEST INDIAN CHERRY (Malpighia glabra L.) AND PINEAPPLE (Ananas comosus (L.) Meer) JUICES ${ }^{1}$
}

\author{
Sueli T. D.BARROS ${ }^{2, *}$, Elisabete S MENDES ${ }^{2}$, Leila PERES ${ }^{3}$
}

\section{SUMMARY}

West Indian cherry (Malpighia glabra L.) and pineapple (Ananas comosus (L.) Meer) juice clarification by cross-flow UF, using polysulphone hollow fiber and ceramic tubular membranes with, respectively, nominal molecular weight cut off values of 100kDaltons and average pore diameters of $0.01 \mu \mathrm{m}$, were studied. The influence of enzymatic treatment using enzyme concentrations of $20,100 \mathrm{and} 300 \mathrm{mg} / \mathrm{L}$, a time of $90 \mathrm{~min}$ and a temperature of $40^{\circ} \mathrm{C}$ for depectinization was verified. The juices were then clarified in a laboratory scale filtration unit, with an effective filtration area of $0.12 \mathrm{~m}^{2}$ for the polysulphone hollow fiber membrane and of $0.005 \mathrm{~m}^{2}$ for the ceramic tubular membranes. The influence of enzymatic treatment on viscosity, turbidity and total pectin of the juice, before ultrafiltration, is reported. Membrane performance was evaluated in terms of flow rate and clarity of the permeate. The permeate flow rate of depectinized pineapple juice was higher $(30-60 \%)$ for both membranes. Depectinized West Indian cherry juice presented a lower permeate flow rate for the polysulphone hollow fiber membrane. The increase in permeate flow rate, with the use of the $300 \mathrm{mg} / \mathrm{L}$ and $100 \mathrm{mg} / \mathrm{L}$ enzyme concentration was not significant, so it is economically advantageous to ultrafilter depectinized juice, treated with an enzyme concentration of $20 \mathrm{mg} / \mathrm{L}$.

Keywords: clarification; enzyme treatment; ceramic tubular; polysulfone hollow fiber; membrane.

\section{RESUMO}

INFLUÊNCIA DA DESPECTINIZAÇÃO SOBRE A ULTRAFILTRAÇÃO DOS SUCOS DE ACEROLA E ABACAXI. Foi estudada a clarificação através da ultrafiltração por flow rateo cruzado, dos sucos de acerola (Malpighia glabra L.) e Abacaxi (Ananas comosus (L.) Meer), usando membranas de polisulfona fibra oca e tubular cerâmica com peso molecular de corte de $100 \mathrm{kDaltons}$ e diâmetro médio de poro de $0,01 \mu \mathrm{m}$, respectivamente. A influência do tratamento dos sucos, com concentrações de enzima de 20 , 100 e $300 \mathrm{mg} / \mathrm{L}$, tempo de tratamento de $90 \mathrm{~min}$ a temperatura de $40^{\circ} \mathrm{C}$, foi verificada, e então os mesmos foram clarificados numa unidade de ultrafiltração com uma área efetiva de $0,12 \mathrm{~m}^{2}$ para a membrana de polisulfona e de $0,005 \mathrm{~m}^{2}$ para membrana cerâmica. A influência do tratamento enzimático foi avaliada em termos da viscosidade, turbidez e pectina total do suco, antes da ultrafiltração. Os desempenhos das membranas foram avaliados em termos de flow rate permeado e claridade do permeado. O flow rate permeado do suco de abacaxi tratado foi mais alto $(30-60 \%)$ para ambas as membranas do que para o suco natural. O suco de West Indian cherry despectinizado apresentou flow rate permeado menor para a membrana de polisulfona. O aumento de flow rate, observado com $300 \mathrm{mg} / \mathrm{L}$ e $100 \mathrm{mg} / \mathrm{L}$ de enzima não foi significante, concluindo-se que é vantajoso o tratamento com uma concentração de enzima de $20 \mathrm{mg} / \mathrm{L}$.

Palavras-chave: clarificação; tratamento enzimático; cerâmica tubular; polisulfona fibra oca; membrana.

\section{1 - INTRODUCTION}

West Indian cherry (Malpighia glabra L.) and Pineapple (Ananas comosus (L.) Meer) are of commercial and nutritional importance in the tropics, due to their excellent taste (pineapple) and as a natural source of vitamin $\mathrm{C}$ (West Indian cherry) and other important nutrients. Processing and handling juice can affect the quality of the product as shown by several studies on the preservation of the juice nutrients, color, texture and flavor as well as during packaging, storage and transportation [3].

Reduction of product volume using conventional methods such as evaporation, results in losses of many desirable compounds, due to thermal exposure and development of undesirable compounds such as furfural. These limitations can be avoided by using membrane concentration.

\footnotetext{
1. Recebido para publicação em 25/05/2002. Aceito para publicação em 12/05/2004 (000861).

2. Department of Chemical Engineering, State University of Maringá; Colombo Av., 5790;CEP 87020-900 - Maringá-PR; Brazil. Phone: Oxx44261-4323; Fax: 0xx44 - 263-3440; E-mail: sueli@deq.uem.br

3. Polymer Technology Department, School of Chemical Engineering, UNICAMP - SP - Brazil

* A quem a correspondência deve ser enviada.
}

Studies on the filtration of fruit juices for treatment and concentration involved the use of ultrafiltration and reverse osmosis [10]. No appreciable color, aroma and flavor loss was observed during the process as the system does not involve phase change nor heat application [9]. However, only part of the oil soluble flavor compounds were retained by ultrafiltration (UF) membrane, possibly due to their association with the macromolecules [15]. A two-stage concentration process, involving UF with reverse osmosis (RO) was suggested as the best system.

The advantages of cross flow UF of fruit juice include low operating cost, low labor requirements and excellent retention of fresh product quality and appearance [12]. Feed pretreatment either by chemical or biochemical reactions, centrifugation or pre-filtration is very important to minimize fouling of the membrane.

Fruit juice contains colloidal systems. These colloids are part of the fruit itself or may be formed by microorganisms during fruit ripening. Most of the colloids come from the plant itself. The amount of colloids present in fruit juice is in the range of $100-$ $1000 \mathrm{mg} / \mathrm{L}$. An examination of colloids in the juice after pressing, show that they are basically polysaccharides such as pectins and starch.

Pectins are linear polymers essentially composed of $\alpha-1.4$ - linked D - galacturonic acid units 
characterized to a certain extent by methylation of their carboxylic groups [6]. By considering the presence of other sugar units, such as galactose, arabinose and rhamnose as side groups along the galacturonic acid chain, the thickening properties of pectins have been understood. Due to these properties, pectins are responsible for the turbidity and high viscosity of fruit juices. In particular, it has been observed that at the same level of pulp, the viscosity increases as the concentration of pectins is increased, whereas at the same level of pectin the viscosity level remains unchanged even if the pulp content is increased by a factor of 6 [5]. These results suggest that pectin-sugar interactions are responsible for the higher viscosity of a juice.

Pectins make the clarification process hard because of their fiber-like structure. Starch can also lead to difficulties during clarification and cause a secondary haze in juices. Therefore it should not be present in clarified juices [1].

In order to degrade pectins and polysaccharides, an enzymatic treatment of the raw juice is usually carried out with enzymes such as pectinases and amylases. Pectinases hydrolyse pectin and cause pectin protein complexes to flocculate. The resulting juice has a much lower amount of pectin and also a lower viscosity, which is advantageous for the filtration process.

The aim of this work was to determine the influence of the enzyme treatment on the characteristics of the West Indian cherry and pineapple juices and on the ultrafiltration process.

\section{2 - MATERIAL AND METHODS}

\section{1 - West Indian cherry and pineapple juices.}

Frozen West Indian cherry pulp was supplied by the experimental farm at the State University of Maringá. In order to remove most of the pulp, after defrosting, pre-filtration using a $2 \mathrm{~mm}^{2}$ plastic filter was carried out. The juice was standardized at $2 \%$ pulp.

Pineapple juice, previously pasteurized and containing $2 \%$ pulp, was obtained from the Fruteza Juice Industry.

\section{2 - Enzymatic treatment}

The enzymatic treatment was carried out in a $2.5 \mathrm{~L}$ batch reactor immersed in a thermostatically controled bath without stirring. The juices were treated with a mixture of pectinase, hemicellulase and cellulase (Citrozym Ultra-L Novo-Nordisk). This enzyme was used at concentration of 20,100 and $300 \mathrm{mg} / \mathrm{L}$ in the juice with $2 \%$ pulp. The treatment was carried out at a temperature of $40^{\circ} \mathrm{C}$ for one hour and a half. The resulting juice was then processed by ultrafiltration (UF).

\section{3 - Ultrafiltration equipment, membranes and operating conditions}

Experiments were carried out in a UF unit "NETZSCH”, model 027.06-1C1/07-0005/AI, Pomerode
- SC, with which it was possible to use different filtration modules. Two filtration modules were used. The first was made of stainless steel AISI 304, containing a ceramic tubular membrane (material: $\alpha-\mathrm{Al}_{2} \mathrm{O}_{3} / \mathrm{TiO}_{2}$ ) Schumacher GmbH-TI 01070 (porosity $=0.01 \mu \mathrm{m}, \mathrm{ID}=7 \mathrm{~mm}$, $0.05 \mathrm{~m}^{2}$ membrane area). This module was connected by means of Tri-Clamp connections allowing easy dismounting. The second module consisted of polysulfone hollow fibre membrane of AIG Technology Corporation (100kDalton, ID $=1 \mathrm{~mm}, 0.12 \mathrm{~m}^{2}$ membrane area). The UF unit was operated as a recirculating 2.5 liter batch. The feed stream was pumped from a temperature controller tank through the membrane. Permeate was recirculated back into the feeding tank in experiments using a hollow fiber polysulfone membrane, being collected when the ceramic tubular membrane was used. The concentrate returned back to the feed tank. Transmembrane pressure (TMP) was controlled by a valve in concentrate stream. The water flow rate was measured before each test with the juice (TMP $=1$. Obar for hollow fiber and TMP $=4$. Obar for tubular, $\mathrm{T}=30^{\circ} \mathrm{C}$ ).

Operating conditions for the UF were: TMP $=0.8 \mathrm{bar}$ for hollow fiber and TMP=4.0bar for tubular membrane, tangential flow rate of $570 \mathrm{~L} / \mathrm{h}$, temperature of $30^{\circ} \mathrm{C}$ and processing time of one hour and a half. The permeate flow rate was measured with a digital balance.

The UF membrane was carefully cleaned after each experiment with a $\mathrm{NaOH}$ solution, sanitized with $\mathrm{NaCl}$ and rinsed with distilled water. The temperature conditions were $50^{\circ} \mathrm{C}$ for hollow fiber polysulfone and $80^{\circ} \mathrm{C}$ for tubular ceramic membranes.

The ascorbic acid of the West Indian cherry juice, processed by ultrafiltration with both membranes, was determined for an enzyme concentration of $20 \mathrm{mg} / \mathrm{L}$ by a liquid chromatographic method (CLAE), POLESELLO \& RIZZOLO [11]. The recovery of the permeate was determined by the ratio between the ascorbic acid in the permeate to that in the concentrate.

\section{4 - Analytical}

During the enzyme treatment carried out in the batch reactor, $20 \mathrm{~mL}$ samples were taken at regular time intervals, heated for $5 \mathrm{~min}$ in a boiling water bath in order to inactivate the enzymes and hence stop the reaction, and centrifuged (Centrifuga FANEM Excelsa Baby II: 206 - R) at 3000rpm (1609.9g) for $10 \mathrm{~min}$ for samples from hollow fiber and 2000rpm (715.5g) and 5min for samples from ceramic tubular. The samples were analysed for total pectin, turbidity and viscosity.

\subsection{1 - Total pectin}

Two methods were used to determine galacturonic acid, the carbazol and the m-hydroxydiphenol methods [8]. For the first, the samples were taken directly without pectin removal. This method was used in the analysis of the samples taken during the enzyme treatment of the juice feed on the UF ceramic tubular membrane. 
The second method was used for the analysis of the samples taken during the enzyme treatment of the juice feed on the UF hollow fiber polysulfone membrane. In this case, in order to recover the pectin, $30 \mathrm{~mL}$ of 96 vol \% boiling ethanol were added to $10 \mathrm{~mL}$ of juice. A gel containing insoluble solids in the ethanol was formed and then separated by centrifugation and washed carefully several times with 73 vol \% ethanol. Each alcohol insoluble sample was dissolved in distilled water to a volume of $50 \mathrm{~mL}$ and analysed in triplicate for total pectin by mixing $1 \mathrm{ml}$ sample with $6 \mathrm{~mL}$ sulphuric acid in sampling flasks held in an ice water bath. The analysis of galacturonic acid was carried out using the mhydroxydiphenol methods.

\subsection{2 - Turbidity}

Turbidity was determined using a portable datalogging spectrophotometer Hach DR/2010 and reported as Formazin Attenuation Units ( 1 FAU $=1$ NTU).

\subsection{3 - Viscosity}

Viscosity was measured with a Rheotest 2.1 viscometer using a cylinder measuring device $\mathbf{N}$, ratio of radii $(\mathrm{R} / \mathrm{r}) 1.02$, shearing stress range $\left(\tau_{\mathrm{r}}\right)$ of 1.6 to 3.2 $(\mathrm{Pa})$, shearing gradient range of 0.15 to $1.31\left(\mathrm{~s}^{-1}\right)$, and a constant temperature water bath $\left(30^{\circ} \mathrm{C}\right)$.

\section{3 - RESULTS AND DISCUSSION}

\section{1 - Influence of the enzyme treatment on West Indian cherry and pineapple juices properties}

The enzyme treatment of West Indian cherry and pineapple juice mainly influences the following parameters: total pectin content, turbidity and viscosity.

The enzyme treatment was carried out with Citrozym Ultra-L $(300 \mathrm{mg} / \mathrm{L})$ at $40^{\circ} \mathrm{C}$ and without stirring. $20 \mathrm{~mL}$ samples were taken at intervals of $10 \mathrm{~min}$ and the aforementioned parameters analyzed in each sample.

\subsection{1 - Total pectin}

Pectolytic enzymes break down the pectin molecules that facilitate the formation of pectin-protein flakes. Pectin forms a protective coat around suspended proteins in an acid environment $(\mathrm{pH}=3.5)$ where pectin molecules carry a negative charge. This causes them to repel one another. Pectinase degrades this pectin and exposes part of the positively charged protein beneath. The electrostatic repulsion between cloud particles is thereby reduced so that they clump together. As this process takes place, the amount of pectin in the juice decreases, while galacturonic acid monomers and oligomers remain in the juice. The galacturonic compounds do not precipitate with 96 vol \% ethanol and do not contribute to juice turbidity. Even though it has long been known that pectins aggravate clarification, it has to be considered that other polysaccharides may also influence clarification and filtration. Especially starch can lead to difficulties during clarification and cause secondary haze.

The reduction of total pectin is shown in Figure 1. Maximum reduction of pectin was achieved after $80 \mathrm{~min}$.

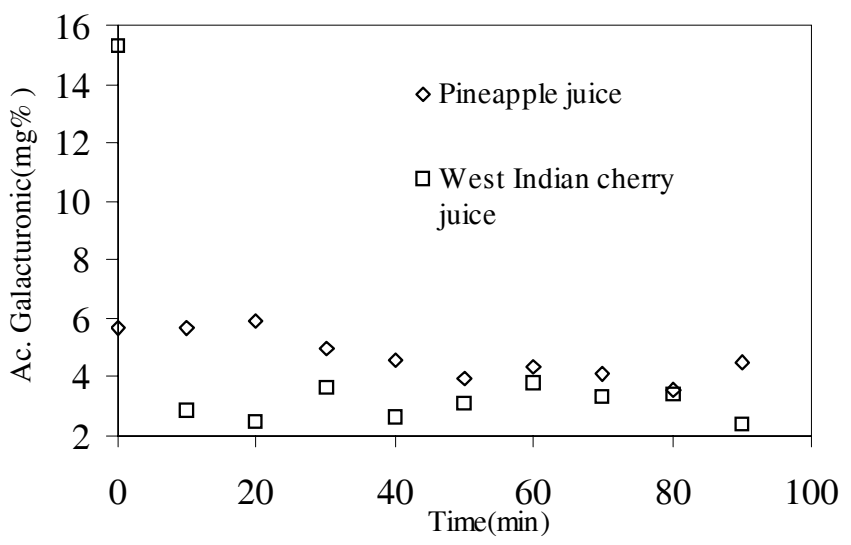

FIGURE 1. Influence of enzyme treatment with Citrozym Ultra-L on the reduction of total pectin (Galacturonic acid) in West Indian cherry and pineapple juice, (300mg/ $\left.\mathrm{L}, 40^{\circ} \mathrm{C}, 90 \mathrm{~min}\right)$

Table 1 shows the reduction in concentration of galacturonic acid for West Indian cherry and pineapple juice at various enzyme concentrations. However for pineapple juice the greater reduction occurred with the lower enzyme concentration and it was much lower than for West Indian cherry juice. As can be seen, pineapple juice has three times less pectin than West Indian cherry juice.

TABLE 1. Concentration reduction of galacturonic acid in West Indian cherry and pineapple juice at various enzyme concentration

\begin{tabular}{c|c|c|c|c}
\hline $\begin{array}{c}\text { Enzyme } \\
\text { concentration } \\
(\mathrm{mg} / \mathrm{L})\end{array}$ & $\begin{array}{c}\text { West Indian } \\
\text { cherry juice } \\
\text { Galacturonic } \\
\text { acid } \\
\text { concentration } \\
(\mathrm{mg} \%)\end{array}$ & Reduction (\%) & $\begin{array}{c}\text { Pineapple juice } \\
\text { Galacturonic acid } \\
\text { concentration } \\
(\mathrm{mg} \%)\end{array}$ & Reduction (\%) \\
\hline 0 & 17.06 & - & 5.18 & - \\
20 & 13.35 & 21.80 & 3.26 & 37.09 \\
100 & 4.15 & 75.70 & 3.41 & 34.13 \\
300 & 3.06 & 82.08 & 3.83 & 26.16 \\
\hline
\end{tabular}

JANSER [7] reported that pineapple has greater amounts of hemicellulose and cellulose than cherries, and that it has a high content of "galactomanann". Galactomanann is a neutral polysaccharide with high water binding capacities and forms viscous solutions, even when highly diluted. For the clarification of pineapple juice it is necessary to use an enzyme preparation with high galactomannase activity together with a broad spectrum of pectolytic, hemicellulytic and cellulytic activities. The analytical methods used to determine total pectin would result in significant errors 
if a high level of carbohydrates were present in the pectin samples [8], so as hemicellulose and cellulose are broken, which can be seen by the reduction in juice viscosity, the galactomanann is liberated from the cell debris liberating galacturonic acid in the juice, which increases as the enzyme concentration increases.

\subsection{2 - Turbidity}

Figure 2 shows the reduction in turbidity during the enzyme treatment of the pineapple juice as a result of haze agglomeration. It can be observed that clarification was completed within approximately $20 \mathrm{~min}$ when all the pectin had not yet been degraded. The decrease in turbidity was fast during the first 10min and much slower afterwards. This behavior was observed by ALVAREZ et al. [1] with apple juice treated with Pectinex 3XL.

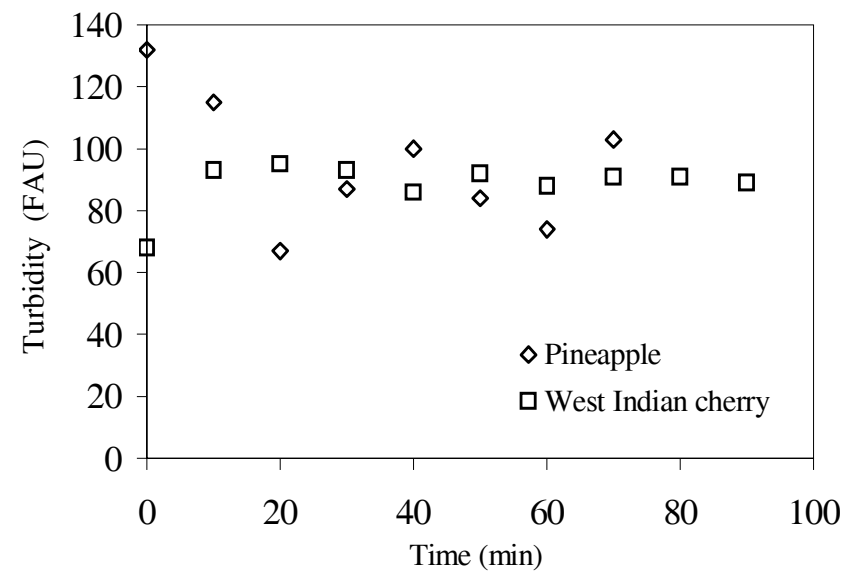

FIGURE 2. Influence of enzyme treatment with Citrozym Ultra-L on pineapple and West Indian cherry juice turbidity, $\left(300 \mathrm{mg} / \mathrm{L}, 40^{\circ} \mathrm{C}, 90 \mathrm{~min}\right)$

The turbidity of West Indian cherry juice increased with time. This behavior was also observed by CHANG et al. [4], working with plum juice from six cultivars when submitted to enzyme treatment and fining. Clarity, as \% transmittance, of Clarex L enzyme extracted juice samples was higher than that of the control in all cases except for the unfined $\mathrm{Au}$ Red plum.

TABLE 2. Turbidity reduction of West Indian cherry and pineapple juice at various enzymes concentrations

\begin{tabular}{c|c|c|c|c}
\hline $\begin{array}{c}\text { Enzyme } \\
\begin{array}{c}\text { concentration } \\
(\mathrm{mg} / \mathrm{L})\end{array}\end{array}$ & $\begin{array}{c}\text { West Indian } \\
\text { cherry juice } \\
\text { Turbidity (FAU) }\end{array}$ & Reduction (\%) & $\begin{array}{c}\text { Pineapple juice } \\
\text { Turbidity (FAU) }\end{array}$ & Reduction (\%) \\
\hline 0 & 67.30 & - & 167.60 & - \\
20 & 91.30 & 35.66 & 139.00 & 17.11 \\
100 & 77.30 & 14.86 & 123.00 & 26.65 \\
300 & 90.30 & 34.18 & 113.30 & 32.44 \\
\hline
\end{tabular}

The turbidity increases with time and with enzyme concentration (Table 2) showing that the enzymatic treatment with pectinase broke down the pectin molecules in to molecules so small that they became soluble in alcohol, which prevented their agglomeration (the reduction in eletrostatic repulsion between cloud particles did not occur) and just a few molecules clumped together, the smallest molecules remaining in suspension causing the increase in turbidity.

\subsection{3 - Viscosity}

The West Indian cherry juice viscosity was reduced by $22.3 \%$ and by $30 \%$ for pineapple juice during the enzyme treatment as shown in Figure 3. This reduction is related to a decrease in the molecular weight of pectins, celluloses and hemicelluloses with time. It was completed within $50 \mathrm{~min}$ when $80 \%$ of the total pectin of West Indian cherry juice and 30\% of the total pectin of the pineapple juice had been depolimerized.

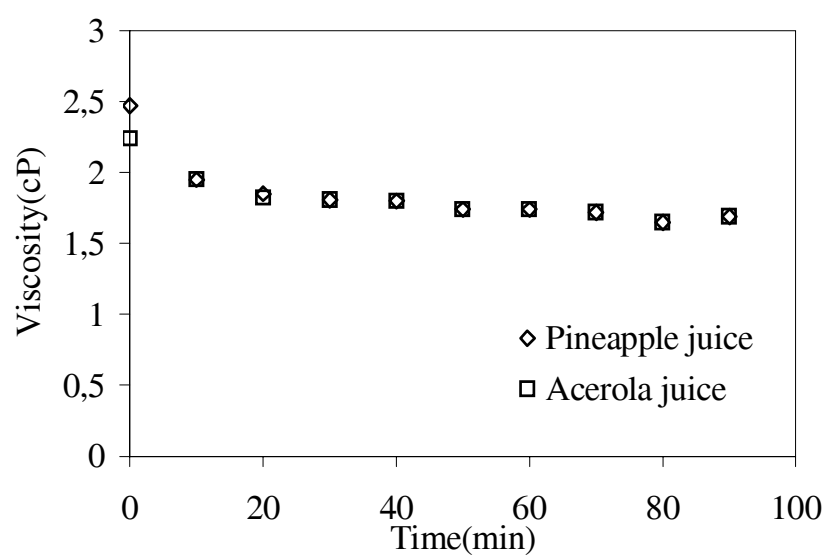

FIGURE 3. Influence of enzymatic treatment with Citrozym Ultra L on pineapple and West Indian cherry juice viscosity, (300mg/L, $\left.40^{\circ} \mathrm{C}, 90 \mathrm{~min}\right)$

Table 3 shows the increase in \% viscosity reduction after one hour and a half of enzymatic treatment with increasing enzyme concentration. This behavior is in accordance with BAUMANN [2], in Birch. An important reduction in viscosity can be noticed, even with small amounts of enzyme (20mg/L), while reduction of the total pectin reached a maximum at an enzyme concentration of 300mg/L for both juices.

TABLE 3. Viscosity percentual reductions with enzyme concentration increase

\begin{tabular}{c|c|c|c|c}
\hline $\begin{array}{c}\text { Enzyme } \\
\text { concentration } \\
(\mathrm{mg} / \mathrm{L})\end{array}$ & $\begin{array}{c}\text { West indian } \\
\text { cherry juice } \\
\text { Viscosity (cP) }\end{array}$ & Reduction (\%) & $\begin{array}{c}\text { Pineapple juice } \\
\text { Viscosity (cP) }\end{array}$ & Reduction (\%) \\
\hline 0 & 2.21 & - & 2.437 & - \\
20 & 1.81 & 18.09 & 1.92 & 21.21 \\
100 & 1.74 & 21.27 & 1.75 & 28.19 \\
300 & 1.67 & 24.43 & 1.67 & 31.47 \\
\hline
\end{tabular}

\section{2 - Influence of enzymatic treatment on ultrafiltration}

Studying the influence of enzyme treatment on UF, several batches of $2.5 \mathrm{~L}$ of West Indian cherry and 
pineapple juice were treated with different amounts of Citrozym Ultra-L for one hour and a half at $40^{\circ} \mathrm{C}$ without stirring. Table 4 shows the characteristics of the juice feed of the UF batches using hollow fiber membranes.

The juices resulting from the enzyme treatment were ultrafiltered at a temperature of $30^{\circ} \mathrm{C}$, at a TMP of $0.8 \mathrm{bar}$ for hollow fiber polysulfone membrane and 4.0bar for ceramic tubular membrane and at a feed tangential flow rate of $570 \mathrm{~L} / \mathrm{min}$ for approximately one hour and a half. In the UF hollow fiber process, retentate and permeate streams were recirculated back into the feeding tank maintaining almost steady state flow.

TABLE 4. Characteristics of pineapple and West Indian cherry juice treated with different amounts of Citrozym Ultra L used in the UF hollow fiber polysulfone process.



Table 4 also shows the juice characteristics at the end of the UF process (retentate) in the feed tank, and of the permeate obtained. As can be seen, total pectins (proportional to galacturonic acid), diminished during the UF process for all enzyme concentrations, except for West Indian cherry juice without enzyme treatment. Treated juices were not inactivated, so the enzymes remained in activity in the juice, breaking the pectins. Pineapple juice showed the most significant reduction in galacturonic acid content and the values are almost the same for the different enzyme concentrations at the end of the UF process as well as having the same viscosities. As a consequence the turbidity diminished too, which can explain why the permeate flow rate increased in the treated juices (Figure 4), reaching almost the same limiting permeate flow rate for all the enzyme concentrations used. Permeation rates were very low, when undepectinized pineapple juice was used, ranging from $44 \mathrm{~kg} /\left(\mathrm{m}^{2} \mathrm{~h}\right)$ at the beginning of the process to $32 \mathrm{~kg} /\left(\mathrm{m}^{2} \mathrm{~h}\right)$ towards the end. The higher viscosity of the undepectinized pineapple juice can explain these results.

A recovery of $166 \%$ of vitamin $\mathrm{C}$ in the permeate of West Indian cherry processed at a temperature of $40^{\circ} \mathrm{C}$ and TMP of 0.8 bar was obtained.

The total pectin content of West Indian cherry juice decreased. The principal reason for this behavior was the passage through the membrane by the small pectin molecules obtained from the enzymatic treatment, causing clogging of the hollow fiber polysulfone membrane channels. Figure 5 shows a decrease in the West Indian cherry juice permeate flow rate with increase in enzyme concentration.

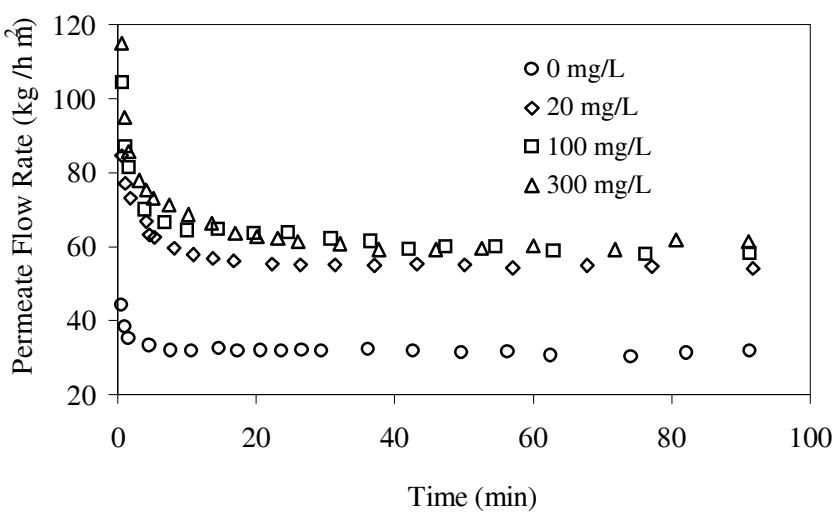

FIGURE 4. Permeate flow rate as a function of time for different enzyme treatments of pineapple juice conducted at $\mathrm{T}=30^{\circ} \mathrm{C} ; \mathrm{P}=0.8 \mathrm{bar} ; \mathrm{Q}=570 \mathrm{~L} / \mathrm{min}$; hollow fiber membrane.

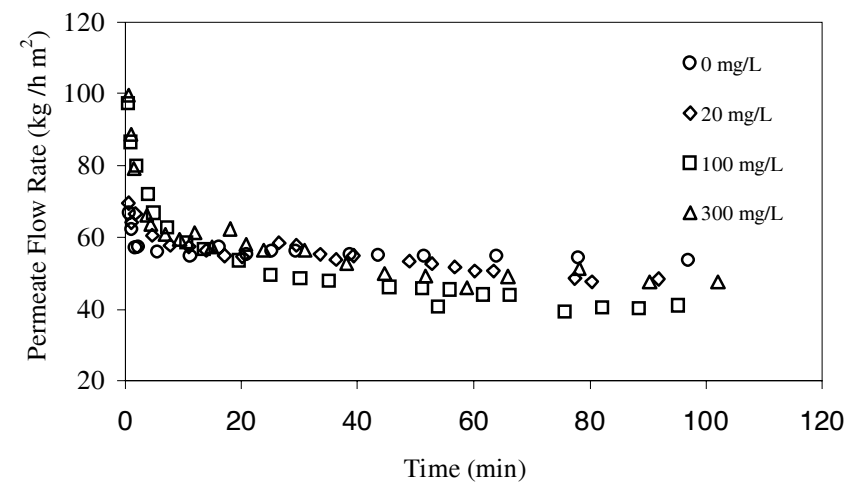

FIGURE 5. Permeate flow rate as a function of time for different enzyme treatments of West Indian cherry juice conducted at $\mathrm{T}=30^{\circ} \mathrm{C} ; \mathrm{P}=0.8 \mathrm{bar} ; \mathrm{Q}=570 \mathrm{~L} / \mathrm{min}$; hollow fiber membrane.

The permeation flow rate decreased with time for all runs. However, the rate of decrease was higher when processing West Indian cherry juice treated with an enzyme preparation concentration of $100 \mathrm{mg} / \mathrm{L}$.

These results can be explained by the work of TODISCO et al. [13]. According to this paper, decreasing the enzyme/substrate concentration ratio resulted in larger amounts of oligomers with molecular weights between 50000 and 10000Da. As the molecular weight 
of these oligomers is similar to the size of the membrane pores, they can completely block the membrane pores and higher fouling can be expected. However, when the enzyme/substrate concentration ratio increases, the concentration of oligomers with molecular weights lower than 2000Dalton increases. These fragments are much smaller than the size of the membrane pores and can easily permeate the membrane. However the polysulfone membrane structure is complex and full of interstitial channels, and thus the decrease in molecular size is not sufficient for all to pass through the membrane.

In this case depectinized permeate juice presents the lowest rate of decline and highest limiting flow rate, since in three minutes it forms a gel layer that blocks the pectin passage, maintaining a stable flow until the end of the process.

The turbidity behavior is according to the above and with the explanations in 3.1.2.

In this work it was observed that turbidity and viscosity changed after heat treatment used to inactivate the samples after enzymatic treatment. The viscosity of pineapple juice was reduced from $3.60 \mathrm{cps}$ to $2.44 \mathrm{cps}$ after heating at $95^{\circ} \mathrm{C}$ for $5 \mathrm{~min}$ and the viscosity of West Indian cherry juice reduced from 2.44 to 2.22 during heat treatment. YEN \& LIN [14] reported that the viscosity decrease in heat-treated guava juice was due to degradation of pectic substances. Turbidity of pineapple was increased from 167.6FAU to 405FAU after heat treatment; the coagulation of degraded pectin combined with other components resulting in the increase in turbidity of guava juice as reported by YEN \& LIN [14]. This behavior justifies the high values for viscosity obtained for juices at the end of the process and in the permeate, since these samples were not inativated. These viscosities had the same values, too,which means that only the pulp of the juice was retained by the membrane surface, allowing all the sugars to permeate. According to DRIOLO \& CALABRO [5], the viscosity increases as the pectin concentration increases, whereas at the same level of pectin the viscosity level remains unchanged, even if the pulp content is increased by a factor of 6 . These results show that pectin-sugar interactions are the most important causes of the high viscosity in the juice.

The high values for turbidity of the permeate juices are due to the large amounts of pectin in the West Indian cherry juice; however these values are reduced $(<2.0 \mathrm{FAU})$ when all the permeate is collected.

Table 5 shows the characteristics of the juice feeding the UF batches using tubular ceramic membrane. Table 5 , also shows the juice characteristics of the UF process, in terms of the concentrate and permeate juice obtained. As can be seen, total pectins (proportional to galacturonic acid) were determined by the carbazol method, but this method is subject to interference from the nonuronide carbohydrates, associated with pectin samples, and removal of this interference often entails considerable manipulation [8]. It is thus difficult to obtain reliable levels of these substances. In Table 5 the galacturonic acid contents are higher in West Indian cherry than in pineapple juice and all of them increase in the concentrate (in this UF process the permeate was all recovered, so the flow was in a transient state). The increase in galacturonic acid with the highest enzyme concentration, confirms the liberation of carbohydrates and colloids when the enzyme breaks the pectin.

TABLE 5. Characteristics of pineapple and West Indian cherry juices treated with different amounts of Citrozym Ultra L, using a UF tubular ceramic membrane process

\begin{tabular}{|c|c|c|c|c|c|c|}
\hline \multirow[b]{3}{*}{ PARAMETERS } & \multicolumn{6}{|c|}{ FEED } \\
\hline & \multicolumn{3}{|c|}{ PINEAPPLE JUICE } & \multicolumn{3}{|c|}{ WEST INDIAN CHERRY JUICE } \\
\hline & $20 \mathrm{mg} / \mathrm{l}$ & $100 \mathrm{mg} / \mathrm{l}$ & $300 \mathrm{mg} / \mathrm{L}$ & $20 \mathrm{mg} / \mathrm{L}$ & $100 \mathrm{mg} / \mathrm{L}$ & $300 \mathrm{mg} / \mathrm{L}$ \\
\hline $\begin{array}{c}\text { Galact Acid - } \\
\text { Carbazol (mg\%) }\end{array}$ & 407.89 & 717.65 & 684.75 & 1412.28 & 1294.95 & 414.47 \\
\hline Turb. (FAU) & 264 & 170 & 353 & 463 & 457 & 330 \\
\hline \multirow[t]{3}{*}{ Viscos. (cP) } & 2.18 & 1.96 & 2.08 & 1.83 & 1.91 & 1.86 \\
\hline & \multicolumn{6}{|c|}{ CONCENTRATE } \\
\hline & \multicolumn{3}{|c|}{ PINEAPPLE JUICE } & \multicolumn{3}{|c|}{ WEST INDIAN CHERRY JUICE } \\
\hline PARAMETERS & $20 \mathrm{mg} / \mathrm{l}$ & $100 \mathrm{mg} / \mathrm{l}$ & $300 \mathrm{mg} / \mathrm{L}$ & $20 \mathrm{mg} / \mathrm{L}$ & $100 \mathrm{mg} / \mathrm{L}$ & $300 \mathrm{mg} / \mathrm{L}$ \\
\hline $\begin{array}{c}\text { Galact Acid - } \\
\text { Carbazol (mg\%) }\end{array}$ & 635.41 & 1026.31 & 1129.93 & 1395.83 & 1410.63 & 1553.11 \\
\hline Turb. (FAU) & 135 & 275 & 436 & 672 & 422 & 523 \\
\hline \multirow[t]{3}{*}{ Viscos. (cP) } & 2.11 & 2.35 & 1.76 & 1.96 & 1.96 & 1.92 \\
\hline & \multicolumn{6}{|c|}{ PERMEATE } \\
\hline & \multicolumn{3}{|c|}{ PINEAPPLE JUICE } & \multicolumn{3}{|c|}{ WEST INDIAN CHERRY JUICE } \\
\hline PARAMETERS & $20 \mathrm{mg} / \mathrm{l}$ & $100 \mathrm{mg} / \mathrm{l}$ & $300 \mathrm{mg} / \mathrm{L}$ & $20 \mathrm{mg} / \mathrm{L}$ & $100 \mathrm{mg} / \mathrm{L}$ & $300 \mathrm{mg} / \mathrm{L}$ \\
\hline $\begin{array}{l}\text { Galact Acid - } \\
\text { Carbazol (mg\%) }\end{array}$ & 915.57 & 1151.31 & 734.1 & 1144.18 & 1381.03 & 978.61 \\
\hline Turb. (FAU) & 12 & 38 & 5 & 1 & 1 & 2 \\
\hline Viscos. (cP) & 2.18 & 2.14 & 1.91 & 1.77 & 1.77 & 1.78 \\
\hline
\end{tabular}

The vitamin $\mathrm{C}$ content of the West Indian cherry processed using a UF tubular ceramic membrane at a temperature of $40{ }^{\circ} \mathrm{C}$ and TMP of 4.0 bar was evaluated obtaining a recovery of $89 \%$ in the permeate.

The feed juices viscosities were very close to one another, however they were different in the concentrate and permeate juices. In this case the permeate had a lower viscosity than the concentrate which means that more substances than pulp were retained by the membrane for all enzyme concentrations.

The turbidity of the concentrated pineapple juice was higher than that of the permeate and feed, but for juice treated with $100 \mathrm{mg} / \mathrm{L}$ of enzyme this value was many times greater than the ideal $(<2.0$ FAU $)$. The permeate flow rate presented a higher rate of decline and a greater presence of galacturonic acid in the permeate for this enzyme concentration. For West Indian cherry juice the turbidity was as expected.

The permeate flow rates are shown in Figures 6 and 7. For both juices they increased with enzyme concentration, except for $100 \mathrm{mg} / \mathrm{L}$ with pineapple juice. As explained before for West Indian cherry juice, this behavior is probably due to the influence of the enzyme/ substrate ratio. A ceramic tubular membrane has a more 
uniform structure with a cylindrical pore and small pectins pass through the membrane with no problem, but for pineapple juice, other constituents like fibers can obstruct the channels, causing the higher rate of decline for the $100 \mathrm{mg} / \mathrm{L}$ concentration of enzyme.

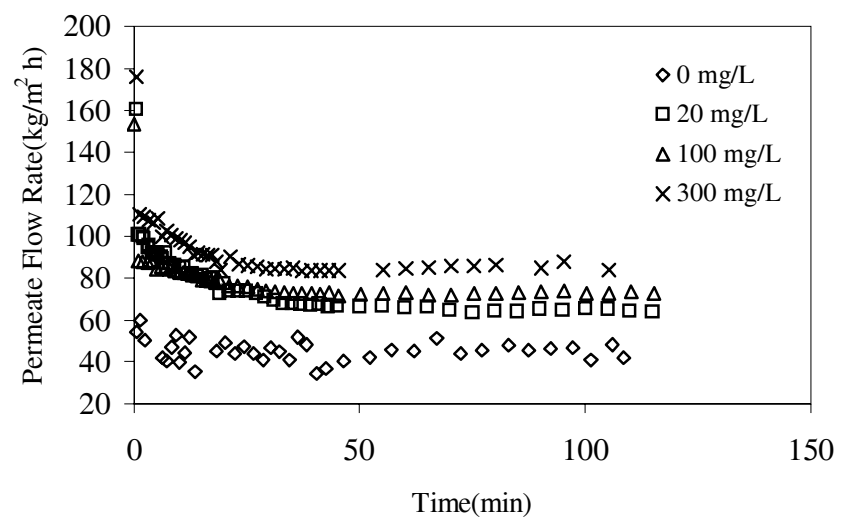

FIGURE 6. Permeate flow rate as a function of time for the different enzyme treatments of West Indian cherry juice conducted at $\mathrm{T}=30^{\circ} \mathrm{C} ; \mathrm{P}=4.0 \mathrm{bar} ; \mathrm{Q}=570 \mathrm{~L} / \mathrm{min}$, ceramic tubular membrane.

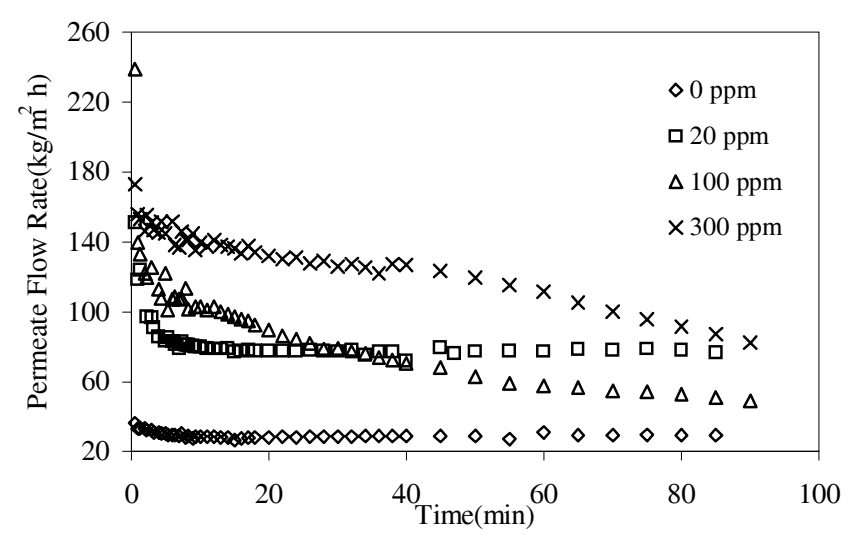

FIGURE 7. Permeate flow rate as a function of time for the different enzyme treatments of pineapple juice conducted at $\mathrm{T}=30^{\circ} \mathrm{C} ; \mathrm{P}=4$. 0 bar; $\mathrm{Q}=570 \mathrm{~L} / \mathrm{min}$, ceramic tubular membrane

\section{4 - CONCLUSIONS}

- The enzymatic treatment of the pineapple juice allowed one to obtain a product with less turbidity, viscosity and total pectin. For the West Indian cherry juice, a product with lower viscosity and total pectin was obtained, even though there was an increase in the turbidity for all the various treatments used.

- The permeate flow rate increased for all treated juices processed using the tubular ceramic membrane, in comparison to the whole juices.

- The limiting flow rate for the permeate of treated West Indian cherry juice, processed using a UF hollow fiber membrane was lower than for the untreated juice. In this case, the enzymatic treatment is not advisable.

- The enzymatic treatment with $20 \mathrm{mg} / \mathrm{L}$ of enzyme, at a temperature of $40^{\circ} \mathrm{C}$ for 60 minutes, was shown to be the most appropriate, allowing the flow rate of the permeate to increase with reduced enzyme expense. The expenditure in enzymes is much lower than that observed in traditional clarification processes, and the enzymes remain in the retentate and can be recycled in the process.

- The recovery of ascorbic acid was higher in the permeate obtained for the juice processed with the hollow fiber polysulphone membrane than for the tubular ceramic membrane.

- Turbidity and viscosity changed after the heat treatment used to inactivate the samples after the enzymatic treatment. The decrease in viscosity during the heat treatment was due to degradation of pectic substances. The turbidity of the pineapple juice increased after heat treatment; the coagulation of degraded pectin combined with other components.

\section{5 - REFERENCES}

[1] Alvarez, S.; AlvareZ, R.; RIERA, F.A.; COCA, J. Influence of depectinization on apple juice ultrafiltration. Colloids and Surfaces A: Physicochemical and Engineering Aspects, v. 138, p. 377-382, 1988.

[2] BAUMANN, J.W. 1981. Application of enzymes in fruit juice technology. In: Birch, G. G., Blakebrough, N. and Parker, K. J. Enzymes and Food Processing, Applied Science Publishers Ltd.

[3] CHAMCHONG, M.; NOOMHORM, A. Effect of pH and enzymatic treatment on microfiltration and ultrafiltration of tangerine juice. Journal of Food Process Engineering, v. 14, p. 21-34, 1991.

[4] CHANG, TUNG-SUN; SIDDIQ, M.; SINHA, N.K.; CASH, J.N. Plum juice quality affected by enzyme treatment and fining. Journal of Food Science, v. 59, n. 5, p. 1065-1069, 1994.

[5] DRIOLI E.; CALABRÓ, V. Membrane Technology in AgroBased Industry. In Workshop on Membrane Separation Process, Proc. ASEAN-EU on Kuala Lumpur, Malasya, july, p. 26-30, 1994.

[6] GIORNO, L.; TODISCO, S.; DONATO, L.; DRIOLO, E. Study of fouling phenomena in apple juice clarification by enzyme membrane reactor. Separation Science and Technology, v. 33, n. 5, p. 739-756, 1998.

[7] JANSER, E. Enzyme applications for tropical fruits and citrus. Fruit Processing, v. 10, n. 6, p. 388-393, 1997.

[8] KINTNER, P.K.; VAN BUREN, J.P. Carbohydrate interference and its correction in pectin analysis using the m-hydroxydiphenyl method. Journal of Food Science, v. 47, n. 3, p. 756-759, 1982.

[9] KIRK, D.E.; MONTGOMERY, M.W.; KORTEKAAS, M.G. Clarification of Pear Juice by Hollow Fiber Ultrafiltration. Journal of Food Science, v. 48, p. 1663-1666, 1983.

[10] MEDINA, B.; GARCIA III, A. 1988. Concentration of orange juice by reverse osmosis. Journal of Food Process Engineering, v. 10, p. 217-230, 1983. 
[11] POlesello, A.; RIZZOlO. A. Application of HPLC to determination of water soluble vitamins in foods: 2 (a review 1985 - 9). Journal of Micronutrient Analysis, v. 8, p. 105-158, 1990.

[12] RAO, M.A.; ACREE, T.E.; COOLEY, H.J.; ENNIS, R.W. Clarification of Apple Juice by Hollow Fiber Ultrafiltration: Flow ratees and Retention of Odor-Active Volatiles. Journal of Food Science, v. 52, n. 1672, p. 375-377, 1987.

[13] TODISCO, S.; PEÑA, L.; DRIOLI, E.; TALLARICO, P. Analysis of the fouling mechanism in microfiltration of orange juice. Journal of Food Processing and Preservation, v. 20, p. 453-466, 1996.

[14] YEN GOW-CHIN; LIN HSIN-TANG. Effects of high pressure and heat treatment on pectic substances and related characteristics in guava juice. Journal of Food Science, v. 63, p. 684-687, 1998.

[15] YU ZER RAN; CHIANG B.H.; HWANG, L.S. Retention of Passion Fruit Juice Compounds by Ultrafiltration. Journal of Food Science, v. 51, n. 3, p. 841-844, 1986. 